\title{
PENGARUH E-LEARNING EDMODO DENGAN MODEL BLENDED LEARNING TERHADAP MINAT BELAJAR
}

\author{
Syifa Fauziyah ${ }^{1}$ dan Mochamad Bruri Triyono ${ }^{2}$ \\ ${ }^{1}$ Program Pascasarjana Universitas Negeri Yogyakarta \\ ${ }^{2}$ Fakultas Teknik Universitas Negeri Yogyakarta \\ email: syifafauziyah.2017@student.uny.ac.id
}

\begin{abstract}
Abstrak
Penelitian ini bertujuan untuk menginvestigasi pengaruh dari pembelajaran e-learning edmodo dengan model blended learning terhadap minat belajar. Jenis penelitian yang digunakan adalah penelitian kuantitatif menggunakan quasy-experimental design with pretestposttest and control group. Pengambilan sampel penelitian dilakukan dengan menggunakan intax group comparison. Jumlah sampel yang digunakan berjumlah 60 siswa yang terdiri dari 2 kelas pada Program Keahlian Teknik Komputer dan Jaringan di salah satu SMK Negeri yang ada di Yogyakarta. Pengumpulan data penelitian menggunakan metode kuisioner dan observasi. Analisis data yang digunakan dalam penelitian ini mengunakan uji-t sedangkan untuk mengetahui efektivitas pembelajaran e-learning edmodo dengan model blended learning menggunakan rumus standart gain dari Ricard R. H. Hasil penelitian menunjukkan bahwa adanya pengaruh yang signifikan antara siswa yang belajar menggunakan e-learning edmodo model blended learning dengan siswa yang belajar dengan bantuan slide presentasi. Selain itu, ditinjau dari nilai gain pada pembelajaran e-learning edmodo dengan model blended learning memiliki kriteria sedang dan pada kelas yang dibelajarkan dengan bantuan slide presentasi memiliki kategori rendah.
\end{abstract}

Kata kunci: e-learning, edmodo, blended learning, minat belajar

\section{THE EFFECT OF EDMODO E-LEARNING USING BLENDED LEARNING MODEL ON LEARNING INTEREST}

\begin{abstract}
This study was aimed at investigating the effect of edmodo e-learning using blended learning model on learning interest. This study used quantitative research combined with quasy-experimental design and pretest-posttest and control group. The sample was chosen using intax group comparison. Sixty students were chosen as the sample of this study consisting of 2 classes of Computer and Network Engineering Expertise Program at one of the State Vocational Schools in Yogyakarta. The data were collected using questionnaire and observation methods. The data then analyzed using t-test. To determine the effectiveness of edmodo e-learning using blended learning model, the standard gain formula proposed by Ricard R.H. was used. The results of this study show that there is a significant effect between the students learning using edmodo e-learning with blended learning model compares to the students learning using presentation slides only. Viewed from the gain value, edmodo e-learning with blended learning model has medium criteria, while the class taught with the aided of presentation slides has a low category.
\end{abstract}

Keywords: e-learning, edmodo, blended learning, learning interest. 


\section{PENDAHULUAN}

Belajar dialami oleh semua manusia. Belajar dianggap sebagai kebutuhan dari manusia. Barron et al. (2015) menyatakan bahwa belajar diartikan sebagai perubahan kebiasaan atau tingkah laku. Belajar adalah perubahan perilaku yang disebabkan oleh praktik atau pengalaman (Lachman, 2010) sehingga dapat dikatakan bahwa belajar merupakan suatu perubahan tingkah laku yang disebabkan oleh pengalaman dilingkungannya. Belajar merupakan bagian dari pendidikan yang memiliki makna yang sangat terstuktur. Dalam Uundang-Undang Nomor 20 Tahun 2003 tentang Sistem Pendidikan Nasional disebutkan bahwa pendidikan adalah salah satu bentuk usaha sadar dan terencana dalam mewujudkan suasana belajar dan pembelajaran agar peserta didik dapat aktif mengembangkan potensi yang dimilikinya sehingga harapannya peserta didik tersebut memiliki kekuatan spiritual, pengendalian diri, kepribadian, kecerdasan, dan akhlak mulia. Kenyataanya masih ditemukan pembelajaran di sekolah yang terpusat pada guru (teacher centered).

Hasil observasi pada tanggal 11 Februari 2019 di SMK Negeri 2 Yogyakarta menunjukkan bahwa bentuk pembelajaran yang berpusat pada guru memiliki kecenderungan bahwa siswa tesebut memiliki sifat pasif pada saat pembelajaran. Guru hanya menyampaikan materi dengan media yang standar. Guru hanya menyampaikan materi lewat slide presentasi yang ditampilkan pada layar LCD. Apabila tidak dimungkinkan dengan media, guru menyampaikan materi dengan ceramah. Siswa hanya bisa mengikuti alur pemberian materi tanpa ada minat atau dorongan dari diri untuk mengembangkan ilmunya. Selain itu, guru kurang memberi tugas kepada siswa untuk eksplorasi atau mengembangkan ilmunya. Padahal minat siswa sangat berperan dalam kegiatan pembelajaran. Minat dapat mendorong siswa mudah memperoleh materi yang disampaikan guru. Dengan minat yang baik terhadap mata pelajaran, siswa akan tertarik mencari pendukung materi baru disamping pembelajaran yang berlangsung di sekolah. Siswa akan terus mencari tahu apa yang menjadi minat atau ketertarikan pada pembelajaran. Siswa tidak akan merasa puas dan terus mengembangkan pengetahuannya.

Ditinjau dari perkembangan teknologi yang pesat seperti saat ini, kebutuhan manusia untuk memperoleh informasi begitu mudah dengan adanya perkembangan internet. Saat ini persentase penggunaan internet di Indonesia amat besar. Asosiasi Penyelenggara Jasa Internet Indonesia (APJII) memaparkan pengguna internet di Indonesia mencapai 143,26 juta atau sekitar 54,7 persen dari total populasi pada tahun 2017. Angka tersebut cukup besar untuk negara berkembang seperti indonesia.

Salah satu bentuk pembelajaran yang memanfaatkan teknologi internet dalam bidang pendidikan adalah e-learning. Aqib (2013, p. 59) menjelaskan bahwa e-learning merupakan suatu bentuk teknologi yang memanfaatkan teknologi elektronik (radio, televisi, film, komputer, internet, dan lain-lain). Penelitian yang dilakukan Nu'man (2014) menemukan bahwa e-learning terbukti mempengaruhi efektivitas pembelajaran. Dengan e-learning pembelajaran akan lebih efektif dari pembelajaran konvensional (berpusat pada guru) yang tinjauannya hasil belajar. Hal ini diperkuat dengan penelitian yang dilakukan Helianak dan Surjono (2014) menyimpulkan bahwa penggunaan e-learning terbukti memiliki hasil yang baik dibanding dengan pembelajaran dengan power point. Hasil yang lebih baik dilihat dari jumlah siswa yang tuntas pada 
saat pembelajaran. Oleh karena itu, dapat disimpulkan bahwa penggunaan e-learning mempunyai peranan dan pengaruh positif dalam pembelajaran.

Penelitian ini berfokus pada Mata Pelajaran Simulasi dan Komunikasi Digital (SKD). SKD merupakan salah satu mata pelajaran yang menyeimbangkan kemajuan teknologi. Mata Pelajaran SKD di Sekolah Menegah Kejuruan (SMK) adalah perkembangan dari Mata Pelajaran Kemampuan Komputer dan Pengelola Informasi (KKPI) pada Kurikulum KTSP 2006 dan hasil revisi dari Mata Pelajaran Simulasi Digital pada Kurikulum 2013. SKD masuk ke dalam kelompok C1 (dasar bidang keahlian) yang berarti semua keahlian di SMK yang menggunakan Kurikulum 2013 revisi 2017 mempelajari mata pelajaran ini.

Salah satu bentuk e-learning yang dapat dimanfaatkan dalam proses pembelajaran pada Mata Pelajaran SKD adalah edmodo. Pada Mata Pelajaran SKD terdapat materi khusus tentang pengoperasian dan pemanfaatan edmodo. Namun, pada saat dilakukan observasi edmodo justru kurang dimanfaatkan. Pada saat pembelajaran, guru cenderung menggunakan slide presentasi dan metode ceramah. Padahal edmodo sendiri merupakan platfrom media sosial yang menawarkan berbagai manfaat di antaranya adalah untuk berbagi file dalam bentuk agenda kegiatan dan penugasan yang dapat menciptakan interaksi antarguru dan siswa. Interaksi siswa dan guru ini yang dapat memicu penumbuhan minat belajar. Hal ini didasarkan pada definisi minat belajar menurut Olivia (2007, p. 15) yang menyatakan bahwa minat belajar adalah keinginan atau kemauan siswa untuk mengikuti pembelajaran. Sehingga dapat diasumsikan bahwa edmodo memungkinkan untuk peningkatan kualitas belajar siswa dalam hal ini adalah minat belajar siswa.
Seorang siswa tertarik dalam proses pembelajaran karena ada faktor-faktor yang mempengaruhinya. Faktor-faktor yang mempengaruhi minat belajar setiap orang berbeda. Syah (2003, p. 132) menyebutkan bahwa faktor minat belajar dibagi menjadi tiga macam yaitu faktor internal, faktor eksternal, dan pendekatan belajar. Faktor internal terdiri dari psikologis (intelegensi, bakat siswa, sikap siswa, minat siswa, motivasi siswa) dan fisiologis (kondisi fisik yang baik dapat mempengaruhi semangat dan intensitas siswa dalam proses pembelajaran). Faktor eksternal terdiri dari lingkungan sosial (sekolah, keluarga, masyarakat dan teman sekelas) dan lingkungan nonsosial (gedung sekolah peletakannya, materi yang diperoleh pada saat pelajaran, waktu belajar, dan alatalat belajar). Faktor yang terakhir adalah pendekatan belajar yang berkaitan dengan segala macam cara atau strategi yang digunakan oleh siswa untuk menunjang keefektifan memahami materi tertentu.

Ditinjau dari pembelajaran di SMK, kebutuhan interaksi antarguru dan siswa dalam mendalami materi yang sifatnya praktik membutuhkan waktu yang banyak. Penelitian Aeni, Prihatin, dan Utanto (2017) menemukan bahwa dalam proses pembelajaran diperlukan interaksi dan komunikasi guru dan peserta didik yang banyak. Keadaan yang ada ketersediaan waktu tatap muka dalam pembelajaran masih kurang. Kurangnya waktu yang diperlukan dalam proses pembelajaran dapat diatasi dengan adanya pembelajaran tambahan di luar sekolah. Salah satunya menggunakan e-learning dengan bantuan edmodo yaitu model blended learning.

Abdussakir (2013) menyatakan bahwa peran guru dalam pembelajaran adalah pusat dari pembelajaran dan tidak dapat diganti oleh media apapun termasuk perangkat komputer. Peran komputer dan guru 
dalam pembelajaran adalah untuk saling melengkapi, tidak untuk saling bersaing atau saling menggantikan. Komputer yang digunakan untuk pembelajaran tidak lain hanyalah alat bantu dalam proses pembelajaran. Selain itu, pembelajaran yang melibatkan peran komputer dan guru (blended learning) lebih efektif daripada dengan guru saja atau komputer saja. Jadi dapat dikatakan jika penerapan e-learning akan lebih baik jika dilakukan sebagai pelengkap pembelajaran di dalam atau di luar kelas di samping keikutsertaan siswa di pembelajaran konvensional. Dari kajian pendahuluan ini dimungkinkan terdapat pengaruh yang signifikan pada pembelajaran e-learning edmodo dengan model blended learning terhadap minat belajar.

\section{METODE}

Penelitian ini merupakan penelitian eksperimen semu dengan pembuktian kuantitatif. Desain penelitian ini menggunakan quasy-experimental design with pretestposttest and control group. Sampel penelitian adalah semua siswa Program Keahlian Teknik Komputer dan Jaringan (TKJ) di SMK Negeri 2 Yogyakarta yang berjumlah 60 siswa pada Tahun Ajaran 2018/2019. Pengambilan sampel penelitian dilakukan dengan menggunakan intax group comparison untuk penentuan kelas eksperimen dan kelas kontrol. Kelas eksperimen adalah kelas yang menggunakan pembelajaran e-learning edmodo dengan model blended learning dan kelas kontrol adalah kelas yang menggunakan pembelajaran dengan slide presentasi.

Data diperoleh dari observasi dan kuisioner minat belajar. Observasi dilakukan dengan pengamatan langsung sedangkan kuisioner tentang minat belajar berbentuk modifikasi skala likert.
Modifikasi skala likert bertujuan untuk mengetahui kecendrungan jawaban yang diberikan siswa. Disediakan empat buah alternatif jawaban untuk setiap butir soal yang diajukan sebagai berikut: 1 (sangat tidak setuju), 2 (tidak setuju), 3 (setuju), 4 (sangat setuju). Indikator/kisikisi kuisioner yang digunakan berasal dari faktor-faktor yang mempengaruhi minat belajar yang terdiri dari aspek kesadaran diri, perhatian, kecakapan berfikir rasional (pendekatan belajar), kecakapan sosial, mengevaluasi, rasa ingin tahu, pengaruh fisiologis, dan pengaruh eksternal. Kuisioner dikembangkan mandiri namun sudah dilakukan perhitungan validitas dan reliabilitasnya. Pengujian validitas menggunakan rumus product moment dan reliabilitas menggunakan rumus Cronbach Alpha. Adapun hasil uji coba reliabilitas minat belajar diperoleh nilai 0,742 dengan kategori tinggi.

Setelah instrumen dinyatakan valid kemudian instrumen digunakan dalam penelitian. Analisis hipotesis menggunakan independent-samples t-test pada SPSS 18. Namun sebelum dilakukan analisis, data dilakukan uji prasyarat analisis yang meliputi uji nomalitas dengan Kolmogorov Smirnov dan uji homogenitas menggunakan Levene test. Kriteria pengujian pada analisis data: jika $(p$-value $)<0,05$; maka hipotesis nol ditolak dan jika ( $p$-value $)>0,05$; maka hipotesis nol diterima. Rumus (1) digunakan untuk menghitung kriteria keefektifan, menggunakan perhitungan n-gain (Richard, 1998, p. 65). Kriteria pada nilai $n$-gain disajikan dalam Tabel 1.

$$
\langle g\rangle=\frac{\text { skor posttest }- \text { skor pretest }}{\text { skor maksimum -skor pretest }}
$$

\section{HASIL PENELITIAN DAN PEMBAHASAN}

Sampel yang digunakan dalam penelitian ini adalah kelas X TKJ 1 dan X 
Tabel 1

Kriteria Nilai n-gain

\begin{tabular}{cc}
\hline Nilai $g$ & Kriteria \\
\hline $0,7<g<1$ & Tinggi \\
$0,3 \leq g \leq 0,7$ & Sedang \\
$0<g<0,3$ & Rendah \\
\hline
\end{tabular}

TKJ 2 di SMK Negeri 2 Yogyakarta pada Tahun Ajaran 2018/2019. Kelas X TKJ 1 yang berjumlah 30 siswa berlaku sebagai kelas kontrol yang pada saat pembelajaran berlangsung hanya mengandalkan slide presentasi. Kelas X TKJ 2 yang berjumlah 30 siswa berlaku sebagai kelas eksperimen yang pada saat pembelajaran berlangsung siswa tidak hanya tatap muka di depan kelas, tetapi diberi pembelajaran e-learning dalam bentuk edmodo (blended learning).

Jumlah pertemuan yang dilakukan pada masing-masing kelas sebanyak 3 kali pertemuan. Jumlah pertemuan dirancang sesuai dengan silabus yang digunakan di sekolah. Rincian pertemuan pada penelitian ini disajikan pada Tabel 2 .

Setelah diperoleh data penelitian, dilakukan perhitungan skor minat belajar pada kelas kontrol dan kelas eksperimen. Berdasarkan hasil perhitungan diperoleh data minat belajar siswa sebelum dan sesudah dilakukan tindakan yang dapat dilihat pada Tabel 3.

Berdasarkan Tabel 3, jumlah skor minat yang diperoleh pada saat sebelum tindakan di kelas eksperimen atau kelas yang diberi perlakuan e-learning edmodo dengan model blended learning memiliki jumlah skor yang tidak jauh berbeda daripada jumlah skor minat yang diperoleh pada kelas kontrol. Selain itu, skor ratarata kelas eksperimen memiliki skor yang tidak jauh berbeda daripada kelas kontrol. Namun, pada nilai posttest minat belajar, jumlah skor minat yang diperoleh pada saat sesudah dilakukan tindakan di kelas eksperimen atau kelas yang diberi perlakuan e-learning edmodo dengan model blended learning memiliki jumlah skor yang lebih besar daripada jumlah skor minat yang diperoleh pada kelas kontrol. Selain itu, skor rata-rata kelas eksperimen lebih besar daripada kelas kontrol.

Ketika ditafsirkan dalam bentuk grafik pada Gambar 1 terlihat bahwa terdapat pengaruh yang baik pada kelas eksperimen yaitu kelas yang diberi perlakuan e-learning edmodo dibanding dengan kelas kontrol. Kelas eksperimen memiliki kenaikan nilai yang signifikan dibanding kelas kontrol. Padahal pada saat sebelum dilakukan tindakan, kelas eksperimen memiliki nilai rata-rata yang lebih rendah dibanding dengan kelas kontrol. Pada kelas kontrol memiliki nilai rata-rata 35,26 dan kelas eksperimen memiliki nilai rata-rata 35,13. Pembelajaran e-learning edmodo dengan model blended learning memiliki hasil yang lebih baik dibanding kelas kontrol (Aeni dkk., 2017; Privantiastika \& Nurohman, 2015).

Minat belajar sesudah dilakukan tindakan pada kelas kontrol memiliki rata-rata sebesar 52,73 dan minat belajar sesudah dilakukan tindakan pada kelas eksperimen memiliki rata-rata sebesar 57,83 . Nilai normalitas sesudah dilakukan tindakan pada kelas eksperimen memiliki nilai sig ( $p$-value) sebesar 0,167 dan nilai normalitas kelas kontrol memiliki nilai sig ( $p$-value) sebesar 0,608. Karena nilai normalitas kelas eksperimen dan kelas kontrol lebih besar dari 0,05 maka data dinyatakan normal.

Nilai homogenitas pada kelas eksperimen memiliki nilai sebesar sig ( $p$-value) sebesar 0,066 . Nilai sig ( $p$-value) lebih besar dari 0,05; maka data minat belajar kelas eksperimen homogen. Pada kelas kontrol, nilai homogenitas memiliki nilai sebesar sig (p-value) sebesar 0,071. Nilai sig (p-value) lebih besar dari 0,05; 
Tabel 2

Kegiatan Penelitian

\section{Kelas Kontrol (Slide Presentasi)}

Pertemuan ke-1

- Guru menjelaskan pembelajaran dengan slide presentasi untuk pertemuan selanjutnya.

- Guru menjelaskan materi yang akan dibahas di pertemuan selanjutnya. Siswa ditugaskan mempelajari materi yang akan dibahas.

Pertemuan ke-2

- Pretest

- Siswa difasilitasi guru mempelajari materi (pengertian e-book, kelebihan e-book, konfersi file, pemformatan e-book, file multimedia di e-book, dan daftar isi).

- Pembelajaran dilakukan di laboratorium Mata Pelajaran SKD dengan media power point. Pembelajaran terpusat pada guru.

Pertemuan ke-3

- Siswa difasilitasi guru mempelajari materi (perangkat pembaca $e$-book, membuat sampul, memilih informasi metadata, dan melengkapi metadata).

- Pembelajaran dilakukan di laboratorium Mata Pelajaran SKD dengan media power point. Pembelajaran terpusat pada guru.

- Posttest

Kelas Eksperimen (e-learning berbantuan edmodo)

Pertemuan ke-1

- Guru menjelaskan pembelajaran dengan edmodo untuk pertemuan selanjutnya.

- Guru menjelaskan materi yang akan dibahas di pertemuan selanjutnya.

- Guru mengarahkan siswa untuk masuk pada kelas edmodo.

Pertemuan ke-2

- Pretest

- Siswa difasilitasi guru mempelajari materi (pengertian e-book, kelebihan e-book, konfersi file, pemformatan e-book, file multimedia di e-book, dan daftar isi).

- Pembelajaran dilakukan di laboratorium mata pelajaran SKD dengan e-learning berbantuan edmodo. Siswa dapat mencari informasi di internet dan menanyakan di edmodo apabila terdapat kendala pada saat tatap muka atau di luar tatap muka.

Pertemuan ke-3

- Siswa difasilitasi guru mempelajari materi (perangkat pembaca e-book, membuat sampul, memilih informasi metadata, dan melengkapi metadata).

- Pembelajaran dilakukan di laboratorium mata pelajaran SKD dengan e-learning berbantuan edmodo. Siswa dapat mencari informasi di internet dan menanyakan di edmodo apabila terdapat kendala pada saat tatap muka atau di luar tatap muka.

- Posttest

maka data minat belajar kelas kontrol homogen. Selanjutnya, dilakukan pengujian hipotesis menggunakan independent- samples t-test pada SPSS 18. Berdasarkan pengujian pada minat belajar sesudah dilakukan tindakan diperoleh nilai t sebesar 
Tabel 3

Skor Minat Belajar Sebelum dan Sesudah Tindakan

\begin{tabular}{lcccc}
\hline \multicolumn{1}{c}{ Tindakan } & Jumlah & Rata-rata & $\begin{array}{c}\text { Skor } \\
\text { Terendah }\end{array}$ & $\begin{array}{c}\text { Skor } \\
\text { Tertinggi }\end{array}$ \\
\hline $\begin{array}{l}\text { Minat belajar sebelum menggunakan slide } \\
\text { presentasi (Kelas Kontrol) }\end{array}$ & 1058 & 35,26 & 25 & 39 \\
$\begin{array}{l}\text { Minat belajar sesudah menggunakan slide } \\
\text { presentasi (Kelas Kontrol) }\end{array}$ & 1582 & 52,73 & 35 & 63 \\
$\begin{array}{l}\text { Minat belajar sebelum menggunakan } \\
\begin{array}{l}\text { E-leraning edmodo dengan model blended } \\
\text { learning (Kelas Eksperimen) }\end{array}\end{array}$ & 1054 & 35,13 & 28 & 39 \\
$\begin{array}{l}\text { Minat belajar sesudah menggunakan } \\
\begin{array}{l}\text { E-leraning edmodo dengan model blended } \\
\text { learning (Kelas Eksperimen) }\end{array}\end{array}$ & 1735 & 57,83 & 51 & 70 \\
\hline
\end{tabular}

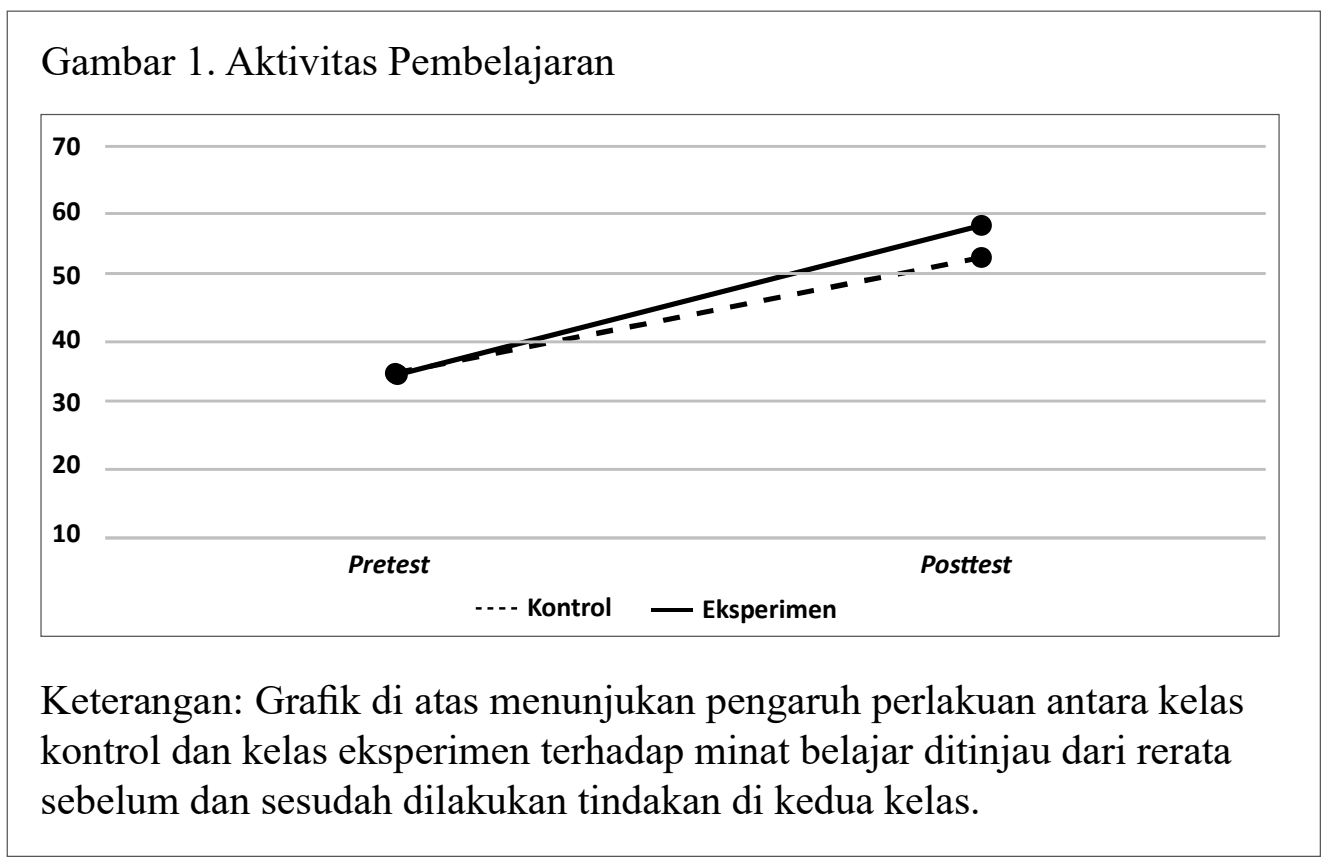

3,422 dengan nilai sig ( $p$-value) sebesar 0,001 . Oleh karena itu, dapat ditarik kesimpulan bahwa terdapat perbedaan yang signifikan minat belajar pada kelas yang diberi perlakuan e-learning berbantuan edmodo dengan kelas yang menerapkan pembelajaran dengan berbantuan komputer (hanya mengandalkan slide presentasi). Hal ini dibuktikan dengan hasil perhitungan nilai sig (p-value) lebih kecil dari 0,05.
Pengukuran kriteria keefektivan minat belajar pada pembelajaran e-learning berbantuan edmodo dengan pembelajaran berbantuan komputer (slide presentasi) dilakukan perhitungan standart gain. Berdasarkan hasil perhitungan nilai $n$-gain minat belajar pada kelas kontrol diperoleh nilai $n$-gain sebesar 0,26 . Nilai $n$-gain adalah 0,26 ; maka nilai $n$-gain minat belajar pada kelas kontrol masuk dalam 
kriteria rendah atau tidak terlalu efektif. Selanjutnya, nilai $n$-gain minat belajar pada kelas eksperimen diperoleh nilai $n$-gain sebesar 0,34 . Nilai $n$-gain 0,34 ; maka nilai $n$-gain minat belajar pada kelas eksperimen masuk dalam kriteria sedang atau pembelajaran e-learning berbantuan edmodo efektif meningkatkan minat belajar siswa.

Pembelajaran e-learning dengan edmodo terbukti efektif meningkatkan minat belajar dibanding pembelajaran yang hanya mengandalkan slide presentasi. Hal ini sejalan dengan penelitian yang dilakukan Privantiastika dan Nurohman (2015) yang menyatakan bahwa penggunaan konten e-learning berbasis edmodo dapat meningkatkan minat belajar siswa dengan nilai $n$-gain sebesar 0,31 dengan kriteria sedang. Dan juga sejalan dengan penelitian yang dilakukan Oktaria, Zulkardi, dan Somakim (2013) yang menyebutkan bahwa pada sebaran angket minat belajar, diperoleh persentase peserta didik berminat sebesar $56,7 \%$ yaitu sebanyak 17 orang berminat. Hal ini dapat disimpulkan bahwa website bahan ajar (e-learning) dapat meningkatkan minat belajar peserta didik.

Berdasarkan hasil jawaban siswa dari kuisioner minat belajar, kebanyakan siswa pada kelas eksperimen mengaku setuju jika e-learning edmodo dengan model blended learning yang ditawarkan menarik. Kemenarikan yang dimaksud dikarenakan selain pembelajaran di kelas, pada saat pembelajaran terdapat aktivitas yang bervariatif seperti kegiatan unggah tugas, mengunduh materi, menanyakan materi yang belum dipahami di luar pembelajaran, mendemostrasikan hasil praktik, dan mengerjakan kuisioner secara online.

Siswa kelompok kelas eksperimen juga mengaku jika suasana kelas kondusif. Suasana tersebut tercipta dikarenakan setiap siswa fokus terhadap pembelajaran yang mereka hadapi. Berbagai bentuk kegiatan pembelajaran yang ditawarkan guru membuat siswa lebih tertarik mempelajari materi sehingga memungkinkan kelas menjadi kondusif. Dukungan seperti perangkat komputer yang sesuai dengan jumlah siswa, edmodo yang dapat diakses dengan bantuan smartphone, dan variasi pembelajaran yang menarik (tidak membosankan) menjadi alasan semakin kondusifnya kelas eksperimen tersebut. Suasana kelas yang kondusif ini mendukung untuk meningkatkan minat belajar siswa dalam memperoleh materi. Suasana kelas yang kondusif dapat dilihat dari hasil pengamatan penelitian yang ditunjukkan pada Gambar 2.

Lewat pemberian tugas pada edmodo, banyak siswa pada kelas eksperimen setuju untuk lebih meningkatkan pengetahuannya pada Mata Pelajaran SKD. Adapun peningkatan pengetahuan yang dimaksud adalah pada saat mempelajari materi pokok, siswa merasa tertantang untuk mencari tahu materi yang menjadi pokok pembahasan lewat berbagai sumber belajar. Hal ini berpotensi untuk peningkatan pengetahuan pada siswa tersebut.

Perasaan tertantang pada saat mempelajari materi pokok memungkinkan siswa memiliki minat belajar yang tinggi terhadap pembelajaran. Banyak siswa juga berpendapat tidak akan menyerah jika diberi tugas yang sulit. Berdasarkan pengamatan pada saat dilakukan penelitian, Siswa tidak merasa cepat puas terhadap materi yang mereka dapat. Siswa terus mencari informasi terkait materi pokok yang sedang menjadi pokok pembahasan. Bahkan pada saat pembelajaran, banyak siswa pada kelas ekperimen aktif menanyakan hambatan yang mereka peroleh pada saat pegerjaan tugas. Pada bagian ini, peran guru sebagai pengontrol/evaluator pembelajaran menjadi hal yang penting. 
Gambar 2. Pembelajaran Kelas Eksperimen

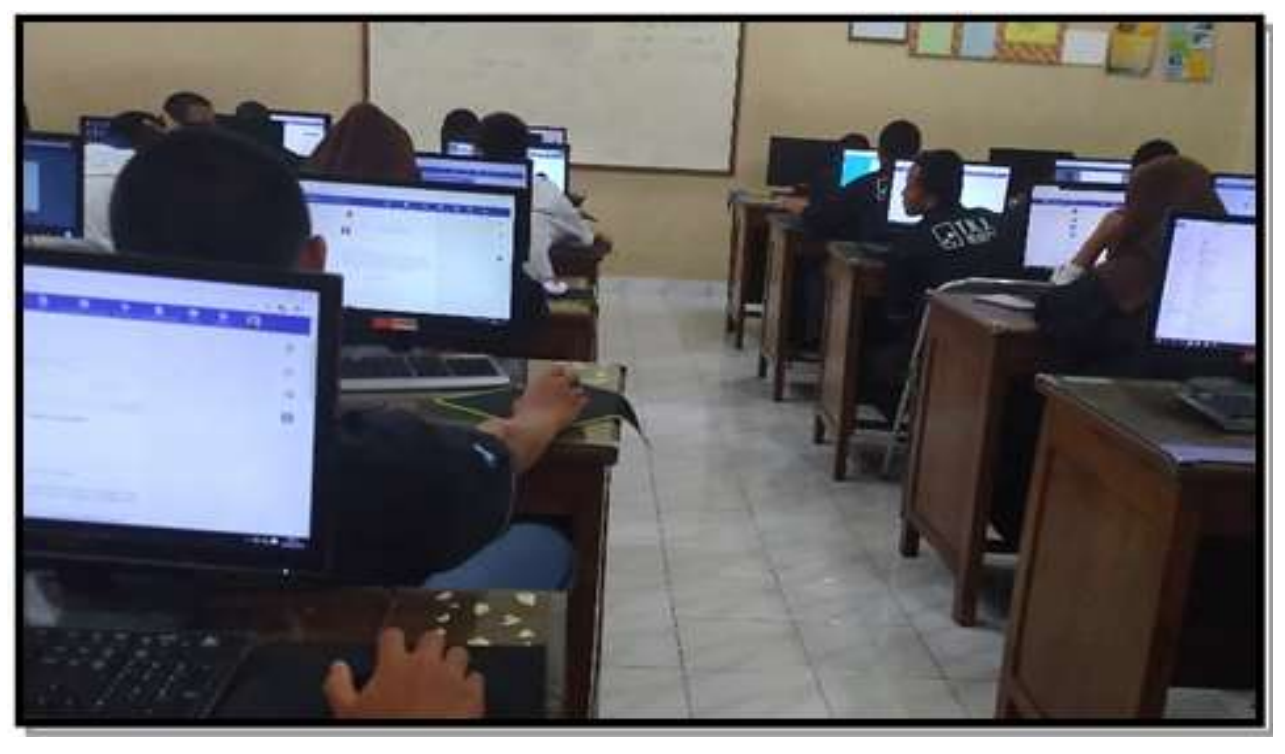

Peran guru sebagai pengontrol/ evaluator pembelajaran di kelompok kelas eksperimen menjadi hal yang penting dikarenakan pada saat pembelajaran di luar kelas, siswa akan terbebas untuk mengeksplorasi yang ingin mereka pahami.

Kebebasan mencari sumber belajar berdampak negatif jika siswa mengeksplor materi secara asal-asalan. Materi yang tidak dapat dipertangungjawabkan kebenarannya akan berpotensi merusak atau menghambat pengetahuan yang diperoleh siswa selanjutnya. Pelajar (gen Y dan Z) cenderung tidak mau memperhatikan (peduli) terhadap keakurasian data dan informasi (Hidayat, Saefudin, \& Sumartono, 2017). Untuk itu, peran guru sebagai pengontrol sangat diperlukan pada saat pembelajaran berlangsung agar materi yang diperoleh dapat tersampaikan dengan baik. Hal ini sejalan dengan penelitian Khairunnisa (2017, p. 413) dan Sundari (2017, p. 60) yang menyatakan bahwa guru memiliki peran pengontrol/evaluator. Kegiatan ini dimaksud untuk mengetahui tujuan yang dirumuskan diawal pembelajaran dapat tercapai atau tidak, apakah materi yang diajarkan sudah cukup tepat atau tidak. Selain peran guru yang dominan pada saat pembelajaran, peran teman di kelas juga menjadi penentu peningkatan minat belajar siswa.

Pada saat penelitian berlangsung, terlihat peran teman-teman sebaya dalam kelas eksperimen tidak hanya sebagai pesaing, tetapi juga sebagai sarana kerja sama untuk memperoleh materi. Bentuk kerja sama di sini terlihat pada saat pembelajaran di kelas dan diluar kelas. Bentuk kerja sama saat pembelajaran tatap muka di kelas terlihat pada saat diskusi kelompok. Bentuk pembelajaran di luar kelas, antarsiswa ataupun dengan guru saling bertukar informasi terkait materi pokok yang dituangkan dalam bentuk diskusi di edmodo.

Pada Gambar 3 terlihat siswa berdiskusi dan menjelaskan materi terhadap teman sekelasnya. Pada saat diskusi banyak siswa antusias saling bertukar informasi terkait materi yang sedang dipelajari. Hal ini sejalan dengan penelitian yang dilakukan Yudha 
Gambar 3. Diskusi dikelas

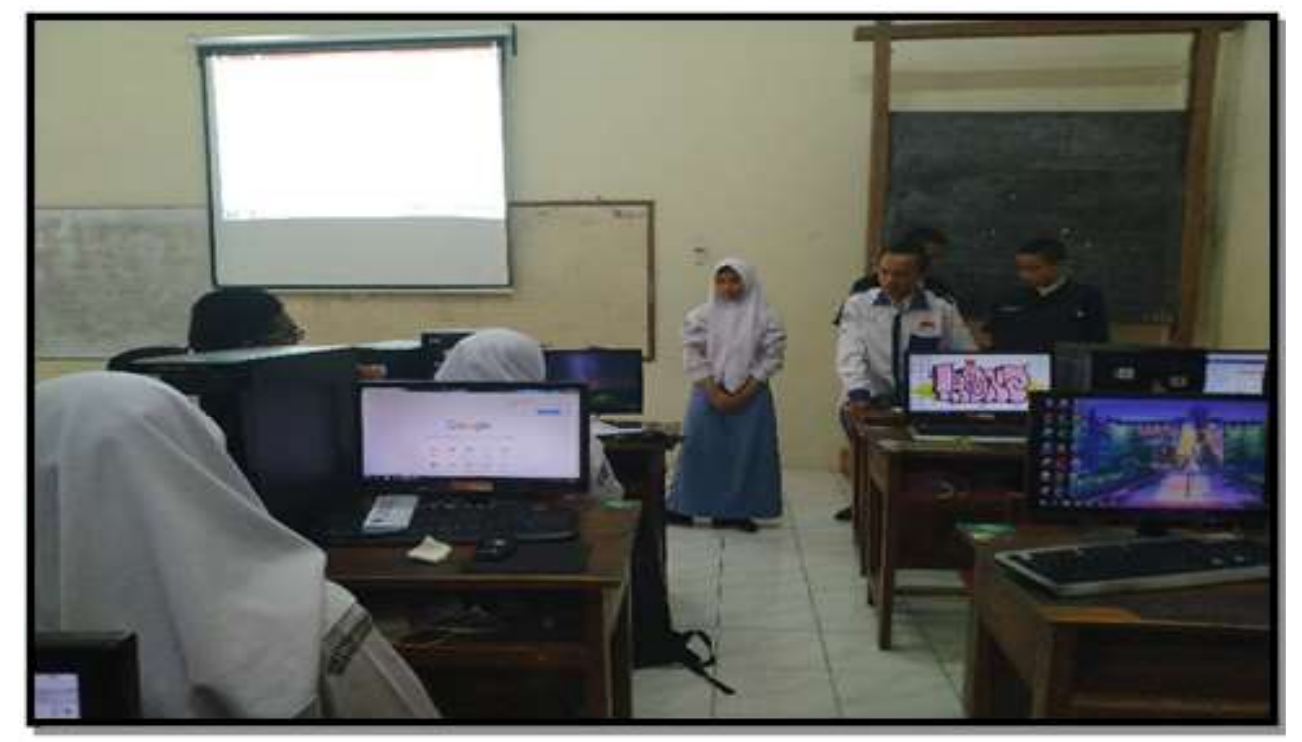

(2018) yang menyatakan bahwa terdapat pengaruh dari peran teman sebaya di kelas dalam meningkatkan minat belajar dengan nilai capaian dari responden sebesar 74,49 dengan kategori baik. Selain itu, didukung pula oleh penelitian yang dilakukan Nap (2016) yang menyatakan bahwa terdapat pengaruh positif dan signifikan antara relasi teman sebaya terhadap minat belajar dengan nilai $\mathrm{F}_{\text {hitung }}=57,358>\mathrm{F}_{\text {tabel }}=3,96$ dengan taraf signifikan sebesar 0,000 .

Selain pembelajaran di kelas, antarsiswa dengan guru juga mendiskusikan materi pokok yang sedang dipelajari pada e-learning edmodo (blended learning). Sama seperti saat tatap muka berlangsung, pada pembelajaran e-learning edmodo terlihat siswa aktif berdiskusi dengan sesama siswa. Hal ini dapat dilihat pada Gambar 4. Pada Gambar 4, terlihat siswa dalam kelas eksperimen antusias dalam mendiskusikan materi yang menjadi topik pembahasan. Topik pembahasan berasal dari materi pokok yang diunggah guru. Siswa terlihat antusias dengan aktif menanyakan dan menjawab terkait materi yang disampaikan lewat kolom komentar pada materi yang telah diunggah guru. Untuk melihat ketertarikan siswa terhadap pembelajaran pada e-learning edmodo dapat juga diamati yang menglik "suka" terhadap posting-an guru dan siapa saja siswa yang melihat posting-an materi dari guru. Hampir semua siswa ikut andil pada bagian ini.

Lingkungan belajar dalam kelas eksperimen yang bersaing membuat siswa terus belajar dengan menanyakan kepada teman-teman atau guru terkait kendala yang dihadapi. Pada jawaban kuisioner minat belajar, hampir semua siswa setuju jika teman-teman yang ada pada kelas eksperimen membuatnya lebih giat mempelajari Mata Pelajaran SKD. Selain pengaruh teman-teman yang ada di kelas, pengaruh guru dalam pembelajaran juga menjadi hal yang penting. Guru yang baik akan mengupayakan pembelajaran yang diampunya selalu menarik. Untuk menambah kemenarikan pembelajaran pada kelas eksperimen, edmodo diintegrasikan/dilink-kan dengan google form untuk melihat 
Gambar 4. Diskusi pada E-learning Edmodo

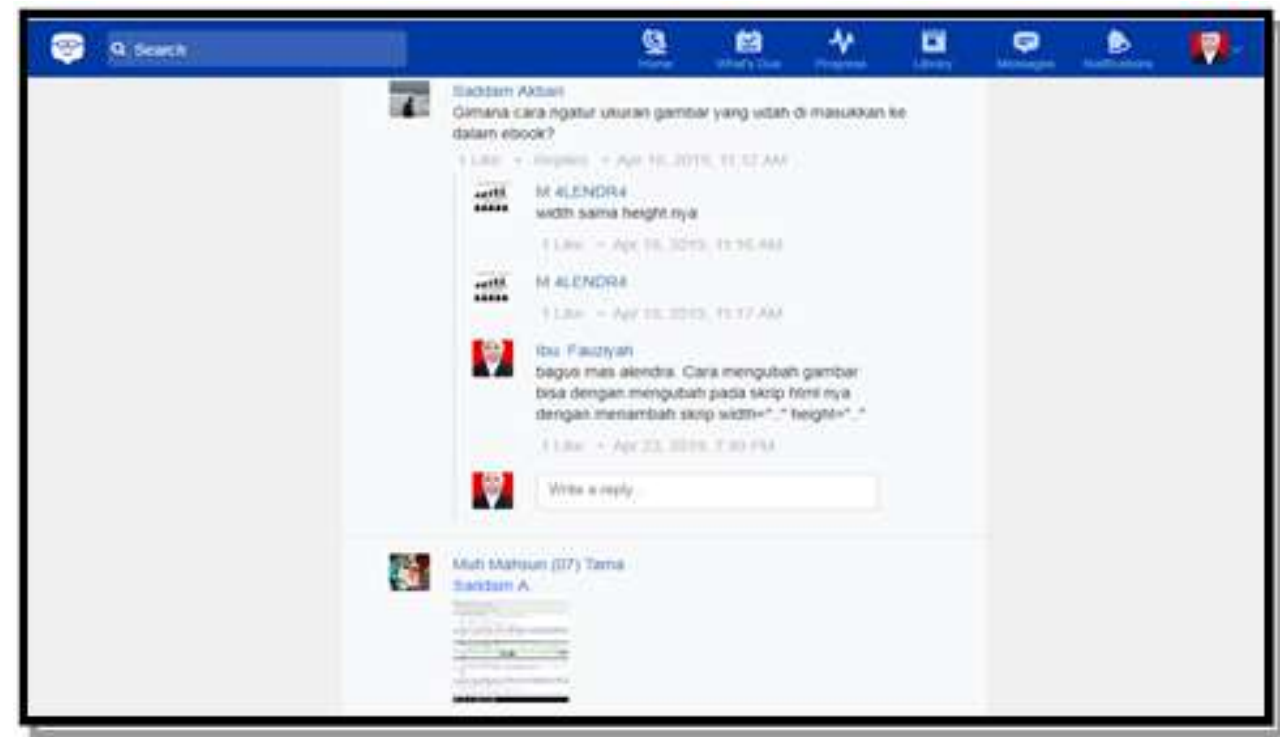

tanggapan siswa mengenai pembelajaran. Tanggapan siswa ini digunakan untuk menjawab minat belajar siswa selama perlakuan/treatment di kelas eksperimen.

Pengisian kuisioner minat belajar pada kelas eksperimen dibatasi dalam waktu satu minggu. Siswa bebas mengisi kuisioner pada saat pembelajaran atau diluar pembelajaran. Hal ini bertujuan agar pada saat pengisian kuisioner diperoleh jawaban yang murni dari siswa yang bersangkutan tanpa ada pengaruh dari luar. Dengan jawaban yang berasal dari siswa tersebut diharapkan bisa menjadi gambaran pembelajaran yang sebenarnya.

Variasi pembelajaran di kelas eksperimen dibuat sevariatif mungkin. Karena tidak hanya tatap muka namun pembelajaran juga disediakan dalam e-learning edmodo. Di e-learning edmodo disediakan berbagai variasi kegiatan seperti unggah tugas, mengunduh materi, menanyakan materi yang belum dipahami di luar pembelajaran, dan mengerjakan kuisioner secara online. Variasi pembelajaran di kelas eksperimen mengacu pada penelitian Nu'man (2014) yang menyatakan bahwa untuk membuat siswa memiliki tanggung jawab dan berperan aktif, maka pembelajaran didesain sevariatif mungkin sehingga siswa akan memperoleh kesempatan membangun pengetahuannya. Pembelajaran variatif yang dimaksud adalah pada saat pembelajaran dengan edmodo siswa diberi kesempatan seperti mengunggah, mengunduh, menjawab kuis secara online, dan menampilkan hasil praktiknya.

Berdasarkan hasil penelitian dan pembahasan, pembelajaran e-learning edmodo dengan model blended learning terbukti efektif digunakan pada pada Mata Pelajaran SKD. Terdapat perbedaan yang sigifikan antara pembelajaran e-learning edmodo menggunakan model blended learning dengan pembelajaran yang hanya mengandalkan slide presentasi. Namun, bukan berati pembelajaran e-learning edmodo menggunakan model blended learning lebih baik dari pembelajaran slide presentasi. Hanya saja pembelajaran e-learning berbantuan edmodo dapat digunakan sebagai alternatif pilihan untuk 
pembelajaran selanjutnya atau pada mata pelajaran lainnya.

Sebelum diterapkan pembelajaran e-learning berbantuan edmodo sebaiknya disiapkan juga beberapa pertimbangan di antaranya sarana dan prasarana (komputer untuk siswa dan guru, koneksi internet), materi/konten yang menarik, bahan pembelajaran, kemampuan guru dan siswa dalam mengoprasikan e-learning, sifat dari materi, dan kondisi di lapangan. Ketersediaan fasilitas pendukung e-learning menjadi bahan pertimbangan yang penting dalam strategi peningkatan penerapan e-learning (Muchlis, 2018; Raharja, 2011). Persyaratan minimal perangkat lunak yang dapat digunakan untuk menunjang perkembangan teknologi informasi meliputi: perangkat lunak sistem maupun aplikasi harus berbasis windows agar mudah dalam pengoperasian, tampilan yang menarik, kesesuaian dengan perangkat keras, dan kecepatan transfer data; meng-gunakan sistem keamanan yang baik; dan menggunakan perangkat lunak berbasis web untuk sistem internet agar jangkauan lebih luas. Tanpa ada pertimbangan tersebut, pembelajaran dengan bentuk apapun tidak dapat meningkatkan dan menghasilkan minat belajar yang baik dari siswa.

\section{SIMPULAN}

Terdapat pengaruh yang signifikan minat belajar antara kelas yang menggunakan e-learning edmodo model blended learning (kelas eksperimen) dengan kelas yang menggunakan pembelajaran menggunakan slide presentasi (kelas kontrol). Hal ini ditunjukan berdasarkan nilai minat belajar pada kelas eksperimen $(\bar{x}=57,83)$ berbeda signifikan dengan nilai minat belajar pada kelas kontrol $(\bar{x}=52,73)$. Hal ini dibuktikan dengan nilai sig ( $p$-value) sebesar 0,001 lebih kecil daripada 0,05.

Pembelajaran e-learning berbantuan edmodo lebih efektif meningkatkan minat belajar pada Mata Pelajaran SKD. Nilai n-gain pada kelas eksperimen memiliki nilai yang lebih besar dibanding kelas kontrol. Berdasarkan perhitungan standar $n$-gain minat belajar kelas eksperimen memiliki kategori sedang dan kelas kontrol memiliki kategori kategori rendah.

\section{DAFTAR PUSTAKA}

Abdussakir. (2013). Penggunaan komputer untuk pembelajaran matematika. Journal Madrasah, 5(2), 117-133.

Aeni, N., Prihatin, T., \& Utanto, Y. (2017). Pengembangan model blended learning berbasis masalah pada mata pelajaran sistem komputer. Innovative Journal of Curriculum and Educational Technology, 6(2), 84-97. Diunduh dari https://journal.unnes.ac.id/sju/index. php/ujet/article/view/15642/9212.

Aqib, Z. (2013). Model-model, media, dan strategi pembelajaran kontekstual (Inovatif). Bandung: CVYrama Widya.

Barron, A. B., Hebets, E. A., Cleland, T. A., Fitzpatrick, C. L., Hauber, M. E., \& Stevens, J. R. (2015). Embracing multiple definitions of learning. Trends in neurosciences, 38(7), 405-407. Diunduh dari https://digitalcommons. unl.edu/cgi/viewcontent.cgi? article $=1$ $058 \&$ context $=$ bioscihebets.

Helianak, A. S., \& Surjono, H. D. (2014). Pengembangan e-learning mata pelajaran teknologi informasi dan komunikasi (TIK) di SMA Negeri 3 Kupang. Jurnal Inovasi Teknologi Pendidikan, 1(1), 1-14. Diunduh dari https://journal.uny.ac.id/index.php/ jitp/article/view/2455/2041.

Hidayat, Z., Saefudin, A., \& Sumartono. (2018). Motivasi, pemikiran kritis dan verifikasi akademik siswa SMA dalam perilaku penemuan informasi. Record and Library Journal, 3(1), 10-24. Diunduh dari https://e- 
journal.unair.ac.id/RLJ/article/ download/7287/4413.

Khairunnisa. (2017). Peran guru dalam pembelajaran. Dalam Prosiding Seminar Nasional Tahunan Fakultas Ilmu Sosial Universitas Negeri Medan (pp. 413-416). Medan: FIS UNIMED.

Lachman, S. J. (2010). Learning is a process: Toward an improved definition of learning. The Journal of Psychology, 131(5), 477-480. Diunduh dari https://www.tandfonline.com/doi/ abs/10.1080/00223989709603535.

Muchlis, M. (2018). Strategi peningkatan penerapan metode pembelajaran e-learning pada program sarjana. Jurnal Kependidikan: Penelitian Inovasi Pembelajaran, 2(1), 141-152. Diunduh dari https://journal.uny.ac.id/ index.php/jk/article/view/9578/pdf.

Nap, Y. (2016). Pengaruh relasi sebaya terhadap minat belajar siswa kelas V SD Gugus 3 Sewon Bantul. Basic Education, 5(7), 719-729. Diunduh dari https://journal.student.uny. ac.id/ojs/ojs/index.php/pgsd/article/ vieFile/1251/1128.

Nu'man, A. Z. (2014). Efektifitas penerapan e-learning model edmodo dalam pembelajaran pendidikan agama Islam terhadap hasil belajar siswa (Studi kasus: SMK Muhammadiyah 1 Sukoharjo). DutaCom Journal, 7(1).

Oktaria, D., Zulkardi, Z., \& Somakim, S. (2013). Pengembangan website bahan ajar turunan untuk meningkatkan minat belajar peserta didik. Jurnal Kependidikan, 43(2), 107-115. Diunduh dari https://journal.uny.ac.id/ index.php/jk/article/view/1965.

Olivia, F. (2007). Membantu anak punya ingatan super. Jakarta: PT Elex Media Komputindo.
Presiden Republik Indonesia. (2003). Undang-undang Nomor 20 Tahun 2003 tentang Sistem Pendidikan Nasional. Jakarta.

Privantiastika, C. I., \& Nurohman, S. (2015). Pengembangan konten e-learning berbasis edmodo pada materi gerak lurus untuk meningkatkan minat belajar siswa di SMA Muhammadiyah 2 Yogyakarta. e-Journal Universitas Negeri Yogyakarta, 4(1). Diunduh dari http://journal.student.uny.ac.id/jurnal/ artikel/10283/46/1169.

Raharja, S. (2011). Model pembelajaran berbasis learning management system dengan pengembangan software moodle di SMA Negeri Kota Yogyakarta. Jurnal Kependidikan: Penelitian Inovasi Pembelajaran 41(1), 55-70. Diunduh dari https://journal.uny.ac.id/index.php/ $\mathrm{jk} /$ article/view/504/368.

Sundari. (2017). Pengaruh guru sebagai pembelajaran dalam memotivasi peserta didik usia SD. Dalam Prosiding Diskusi Panel Pendidikan "Menjadi Guru Pembelajar" Keluarga Alumni Universitas Indraprasta PGRI (pp. 60-76). Diunduh dari https:// journal.lppmunindra.ac.id/index.php/ repository/article/view/1665/1287.

Syah, M. (2003). Psikologi belajar (Cetakan II). Jakarta: PT Raja Grafindo Persada. TimAPJII. (2018). Buletin APJII, 22. Diunduh dari https://apjii.or.id/downfile/file/ BULETINAPJIIEDISI22Maret2018.pdf. Yudha, R. I. (2018). Pengaruh teman sebaya dan minat belajar terhadap hasil belajar siswa kelas VII pada mata pelajaran IPS di SMP Negeri 6 Kota Jambi. ISTORIA: Jurnal Ilmiah Pendidikan Sejarah Universitas Batanghari, 2(1), 108-113. Dunduh dari http://istoria. unbari.ac.id/index.php/OJSISTORIA/ article/download/22/18. 